\title{
MARKET-BASED PERFORMANCE MEASURES: A SHAREHOLDER'S PERSPECTIVE
}

\begin{abstract}
Abu Bawa
Abstract

The concept of performance measurement is an important construct in management and strategic management literature. It is a hotly debated topic and a favourite theme in management research. Since performance measurement is a multi-dimensional construct, there is no consensus as to the choice of independent variable in measuring performance. This article contributes to this debate by presenting the two most popular measures, Price-to-Earnings ratio and the Market-to-Book value, commonly considered as market-based performance measures of profitability from the viewpoint of shareholders. Profitability measures are used as indicators of business financial performance in a multi-dimensional performance model. To assess the financial aspect of firm's performance, researchers generally used either accounting-based or market-based measures. The accounting-based measures are considered back-ward looking and are influenced by accounting standards and management choice of accounting methods. Market-based measures are forward looking and mostly favoured by shareholders. The underlying assumption of the market-based measures is market efficiency, which views stock price as representing the firm's fundamental value. Market based performance measures incorporates all relevant information and thus not limited to only a single aspect of performance unlike the accounting measures. The theoretical basis for using market-based performance measures is that they reflect a firm's financial performance more accurately compared to the accounting-based measures.
\end{abstract}

Keywords: performance measures, financial performance, shareholder, strategic management

\section{INTRODUCTION}

Financial performance is widely believed to represent the fulfilment of the economic goals of the firm. In a multi-dimensional representation of organizational effectiveness, Venkatraman and Ramanujan (1986) used three concentric overlapping circles to explain the interrelationship between Organizational effectiveness, Business performance and Financial performance. The inner circle represents financial performance, which is assumed to fulfil the economic goals of the firm. The most commonly used indicators to measure financial performance are sales growth, profitability measures, earnings per share, market-to-book, stock market returns and Tobin's Q (Hax \& Majluf, 1984; Kudla, 1980; Montgomery \& Singh, 1984; Lindenberg \& Ross, 1981; Venkatraman \& Ramanujam, 1986). The medium circle, which is referred to as the business performance, is made up of both operational performance and the financial performance. The operational performance is non-financial in nature. None-financial indicators include market share, product quality, new product introduction etc. Organizational effectiveness, which is represented by the outermost circle, extends the business performance to include organizational goals and influence of multiple stakeholders.

Business performance and its measurement continue to challenge researchers because of its complexity and diverse approaches used by researchers. The use of stakeholder satisfaction approach in measuring business performance has been adopted in earlier works (Clarkson, 1995; Kaplan \& Norton, 1992; Richard et al., 2009; Venkatraman \& Ramanujan, 1986) 
Stakeholders according to Freeman (1984) are "any group or individual who can effect or is affected by the achievement of the organization's objectives" (Santos \& Brito, 2002). This definition gives rise to a lot of unmanageable stakeholders. Many scholars (Clarkson, 1995; Donaldson \& Preston, 1995; Mitchell, Agle \& Wood, 1997) offered different methods of identifying and selecting stakeholders. This paper adopts the method taken by Santos and Brito (2002). Stakeholders identified in the annual reports of selected companies are shareholders, customers, employees, government and society.

The aim of this paper is to contribute to this effort by looking at available market-based indicators frequently used in annual reports to measure financial performance of a business from the viewpoint of shareholders.

\section{DIMENSIONS OF PERFORMANCE MEASUREMENT}

The indicators used to measure different aspects of business performance has been found to be multidimensional (Baum \& Wally, 2003; Cho \& Pucik, 2005; Combs, Crook \& Shook, 2005; Johnson \& Greening, 1999; Rowe \& Morrow, 1999; Sila \& Ebrahimpour, 2005; Silverman, Nickerson \& Freeman, 1997).

Using the Venkatraman and Ramanujan's (1986) conceptual model in which performance has two-second order dimensions: Financial, represented by profitability, growth and market value; and the operational domain that includes the nonfinancial operational measures like customer satisfaction, quality, employee satisfaction, and innovation. The model can be depicted as follows as in Figure 1.

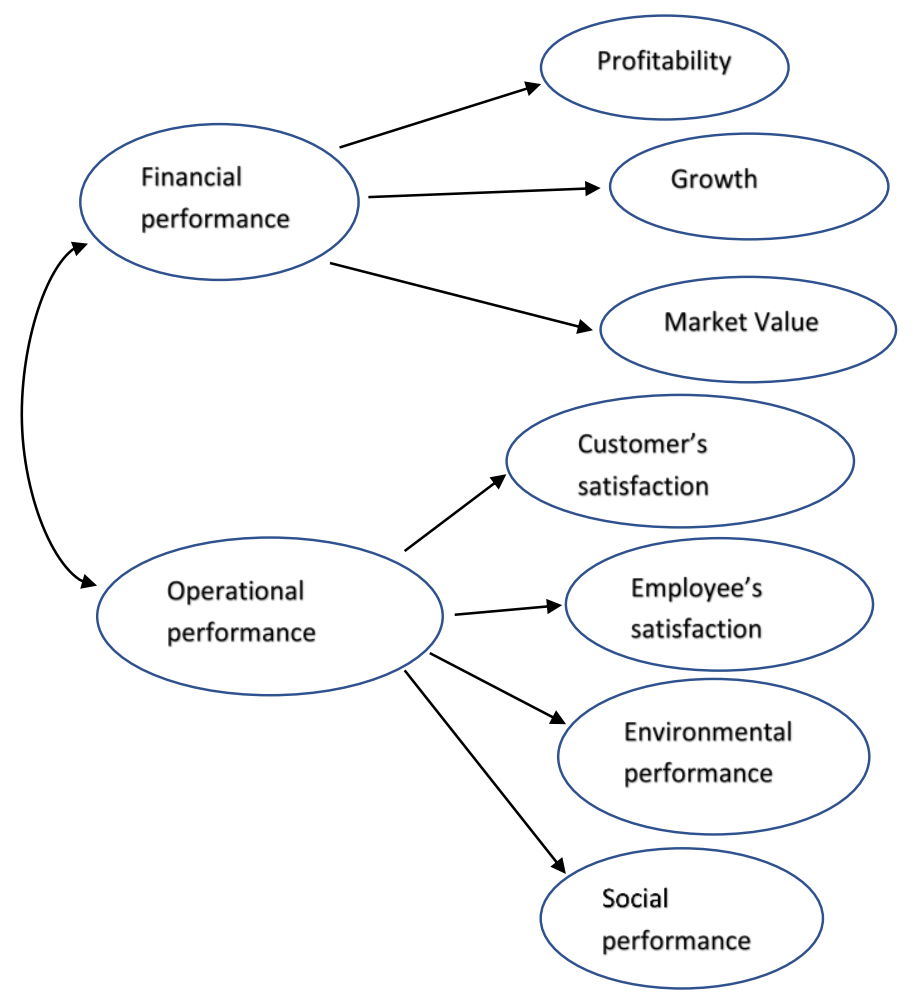

Fig. 1 - Multidimensional performance measurement. Source: Venkatraman \& Ramanujan (1986)

The profit dimension is the most widely used measure of firm's performance because it assesses the fulfilment of the economic goal of the firm. The two main approaches used by researchers to measure the profitability dimension can be broadly classified as Accounting based measures and Market based measures. 
The accounting measures are generally considered to be effective measures of firm's profitability. These measures are ROE, ROA, ROS, PM, ROI etc. Accounting based profit measures are criticised for being back-ward looking. Profit as an accounting measured is influenced by accounting standards and choice of accounting methods of assessing tangible and intangible assets (Kapopoulos \& Lazaretou, 2007).

\section{MARKET BASED PERFORMANCE MEASURES}

Market based performance measures are characterised by their forward-looking aspects and reflects expectations of shareholders concerning future performance of the company (Wahla, Shah \& Hussain, 2012; Shan \& McIver, 2011; Ganguli \& Agrawal, 2009).

Hence, market measures focus on the stock market's evaluation of the firm's performance. The most commonly used performance measures are stock price and earnings per share, hence the P/E ratio, and Market-to-Book Value (Thune \& House, 1970; Rumelt, 1974; Kudla, 1980; Bourgeois, 1980; Hofer, 1980)

The underlying assumption of the market measures is based on market efficiency, which views stock price as representing the firm's fundamental value. Market based performance measures incorporates all relevant information and thus not limited to only a single aspect of performance unlike the accounting measures (Lubatkin \& Shrieves, 1986). The theoretical basis for using market-based performance measures is that they reflect a firm's financial performance more accurately compared to the accounting-based measures. Market-based measures are different from the accounting-based measures because they focus on the present value of future inflow of income, whereas accounting-based measures focus on past performance (Seth, 1990). Furthermore, market measures are immune to the deceptive managerial practices or accounting conventions under the assumptions that the efficient market can see through such distortions (Rowe \& Morrow, 1999)

However, Hoskisson, Johnson and Moesel (1994) and Jacobsen (1988), suggested that past performance represented by accounting measures are good predictors of future performance measured by the market-based measures. They found a significant positive relationship between accounting-based measures and market-based measures of financial performance. Therefore, empirically, the two measures appear to be quite similar, hence separate dimensions of a single underlying construct of firm financial performance.

\subsection{Price-to-Earnings (P/E) ratio}

The $\mathrm{p} / \mathrm{E}$ ratio is the measure of the market confidence in the earning potential of the firm. This ratio is reported in almost all annual reports of quoted companies. The ratio is calculated as $\mathrm{P} / \mathrm{E}$ ratio $=$ Market price per share/Earnings per share. Alternatively, if the required data is not available, then using Gordon Growth Dividend Discount Model, PE ratio can be calculated as (Fun \& Basana, 2012):

$$
\frac{P_{0}}{E_{0}}=\frac{D_{0} / E_{0} \times(1+g)}{E_{0}-r}
$$

Where $\mathrm{D}_{0} / \mathrm{E}_{0}$ is the dividend payout ratio, $\mathrm{g}$ is expected constant dividend growth rate, and $\mathrm{r}$ is the stock's required rate of return. From this equation, it is evident that dividend payout ratio and expected growth rate have positive relationship with $\mathrm{P} / \mathrm{E}$ ratio while stock's rate of return is inversely related. It is the expectation that the higher the ratio is then the better is the market expectations of the earning potential, hence future profitability. The $\mathrm{p} / \mathrm{E}$ ratio is very efficient and practical. Investors and analyst have long been using the $\mathrm{p} / \mathrm{E}$ ratio to help determined if individual stocks are reasonable priced. There are some measurement issues in measuring the 
$\mathrm{p} / \mathrm{E}$ ratio. The first issue is related to the time frame. The price in the $\mathrm{P} / \mathrm{E}$ ratio is usually the current market price, such as a weekly average, or daily closing price. However, the earnings used is usually the realized earnings from the past year or average of annual earnings for the past few years or forecasted earnings for the future (Shen, 2000). Hence trailing P/E ratio and forward $\mathrm{P} / \mathrm{E}$ ratio. The forward $\mathrm{P} / \mathrm{E}$ ratio, which divides stock price by forecasted earnings, is less affected by nonrecurring earnings. In the literature, it is demonstrated that forward-looking earnings are more valuable than historical earnings (Dechow, Hutton \& Sloan; 1999, Kim \& Ritter, 1999; Wu, 2014). There exists therefore evidence that the forward P/E ratio explains stock prices better than the historically based financial ratios. Wu (2014) found out that forward $\mathrm{P} / \mathrm{E}$ ratio predicts future earnings growth better than trailing $\mathrm{P} / \mathrm{E}$ ratio.

The relationship between P/E ratio and profitability was first demonstrated by Ohlson and Gao (2006). They used a theoretical model to predict the relation between P/E ratio and return on equity. This relation was empirically demonstrated by Wu (2014). Results showed that the P/E ratio has a U-shaped relation with the return on equity. Firms with higher forward P/E ratios achieve lower ROE in the subsequent years and the distribution of their earnings is more volatile and wide spread than firms with lower P/E ratio (Wu, 2014). Firms with high P/E ratio report higher earnings. Furthermore, using GSCORE, Wu (2014) found out that among high P/E ratio, firms with higher GSCORE report higher earnings growth, sales growth, and ROE in subsequent years.

\subsection{Market-to-book ratio (MB)}

The MB measure is a very good measure of performance because it show the premium or confidence that market places on the firm and therefore reflects the efficiency with which the market views the firm as being managed (Sharma et al., 2013). High premium implies high return for each dollar invested compared to low premium ratio.

The use of the MB ratio as a measure of performance increased significantly in the literature since the mid-1980s (Cho \& Pucik, 2005; Dushnitsky \& Lenox, 2006; Tanriverdi \& Venkatraman, 2005; Sharma et al., 2013). Since the MB uses both accounting and market value indicators of firm performance, it provides a theoretical rationale as a measure of firm performance (Lee \& Makhija, 2009; Sharma et al., 2013; Ceccagnoli, 2009). Usually, earnings manipulations and errors, when present, occur in the income statement and affects earningsbased accounting measures of performance (Fisher \& McGowan, 1983; Amit \& Wernerfelt, 1990). However, a Balance Sheet variable as Book value, is a commulative value and less susceptible to manipulations. The Book Value, as a commulative value, is relatively stable compared to the annual earnings and cash flows. The theoretical rational can be demonstrated as follows using the steady state constant growth dividend discount model (Sharma et al., 2013):

$$
M=\frac{D *(1+g)}{(r-g)}
$$

Where;

$\mathrm{M}=$ Market Value of Equity

$\mathrm{D}=$ Cash Dividends at the beginning of the year

$\mathrm{G}=$ growth rate

$\mathrm{R}=$ required rate of return

Since the dividend paid can be re-written as payout ratio of earnings, the above equation transforms to: 


$$
M=\frac{e * P O *(1+g)}{(r-g)}
$$

Where

$\mathrm{e}=$ Total Net earnings

$\mathrm{PO}=$ Payout ratio (Cash dividend/Total net earnings)

If all earnings are dividends, whether paid out or retained, and dividing both sides of the equation by book Value (B), we get:

$$
\frac{M}{B}=\frac{R O E *(1+g)}{(r-g)}
$$

Thus, theoretically, the Market -to-Book ratio incorporates both performance and risk measures. As shown above in the equation, M/B ratio is a positive function of performance as indicated by the Return on Equity (ROE) and growth (g) and a positive function of the dividend payout ratio. Understand how much control management has over the independent variables is very important for strategic management. Therefore, management action can have more impact on efficiency and growth which in turn impacts firm's performance.

\section{CONCLUSION}

The concept of performance measurement in management and strategic management theory is hotly debated in the literature, unfortunately no one single measure of performance can portray this all-important concept. This article contributes to this debate by presenting the two most popular measures, Price-to-Earnings ratio and the Market-to-Book value, commonly considered as market-based performance measures of profitability from the viewpoint of shareholders. Profitability measures are mostly used as indicators of business financial performance in a multi-dimensional performance model. To assess the financial aspect of firm's performance, researchers generally used either accounting-based or market-based measures. The limitation here is that only the two measures of financial aspect of firm's performance are presented, other market-based measures were not considered, mainly because these two measures are mostly used in annual reports.

\section{References}

Amit, R., \& Wernerfelt, B. (1990). Why Do Firms Reduce Business Risk? Academy of Management Journal, 33(3), 520-533. doi: 10.2307/256579

Baum, R. J., \& Wally, S. (2003). Strategic Decision Speed and Firm Performance. Strategic Management Journal, 24(11), 1107-1129. doi: 10.1002/smj.343

Bourgeois, L. J. (1980). Performance and consensus. Strategic Management Journal, 1(3), 227248. doi: $10.1002 / \mathrm{smj} .4250010304$

Ceccagnoli, M. (2009). Appropriability, Preemption, and Firm Performance. Strategic Management Journal, 30(1), 81-98. doi: 10.1002/smj.723

Cho, H., \& Pucik, V. (2005). Relationship between Innovativeness, Quality, Growth, Profitability and Market Value. Strategic Management Journal, 26(6), 555-575. doi: $10.1002 / \mathrm{smj} .461$ 
Clarkson, M. B. (1995). A Stakeholder Framework for Analyzing and Evaluating Corporate Social Performance. Academy of Management Review, 20(1), 92-117. doi: $10.2307 / 258888$

Combs, J. B., Crook, R. T., \& Shook, C. L. (2005). The Dimensionality of Organizational Performance and its Implications for Strategic Management Research. In D. Ketchen \& D. Bergh (Eds.), Research Methodology in Strategy and Management. Bingley: Emerald. doi: 10.1016/S1479-8387(05)02011-4

Dechow, P. M., Hutton, A. P., \& Sloan, R. G. (1999). An empirical assessment of the residual income valuation model. Journal of Accounting and Economics, 26(1-3), 1-34. doi: 10.1016/S0165-4101(98)00049-4

Donaldson, T., \& Preston, L. E. (1995). The Stakeholder Theory of the Corporation: Concepts, Evidence, and Implications. Academy of Management Review, 20(1), 65-91, doi: 10.5465/AMR.1995.9503271992

Dushnitsky, G., \& Lenox, M. J. (2006). When does corporate venture capital investment create firm value? Journal of Business Venturing, 21(6), 753-772. doi: 10.1016/j.jbusvent.2005.04.012

Fisher, F. M., McGowan, J. J. (1983). On the Misuse of Accounting Rates of Return to Infer Monopoly Profits. American Economic Review, 73(1), 82-97. Retrieved from https://www.jstor.org/stable/1803928

Freeman, R. E. (1984). Strategic Management: A Stakeholder Approach. Cambridge: Cambridge University Press.

Fun, L. P., \& Basana, S. R. (2012). Price Earnings Ratio and Stock Return Analysis. (Evidence from Liquidity 45 Stocks Listed in Indonesia Stock Exchange). Jurnal Manajemen Dan Kewirausahaan, 14(1), 7-12. doi: 10.9744/jmk.14.1.7-12

Ganguli, S. K., \& Agrawal, S. (2009). Ownership structure and firm performance: An empirical study on listed Mid-Cap Indian Companies. IUP Journal of Applied Finance, 15(12), 37-52. Retrieved from https://ssrn.com/abstract=1523669

Hax, A. C., \& Majluf, N. S. (1984). The Corporate Strategic Planning Process. Interfaces, 14(1), 47-60. doi: 10.1287/inte.14.1.47

Hofer, C. W. (1980). Turnaround Strategies. Journal of Business Strategy, 1(1), 19-31. doi: $10.1108 / \mathrm{eb} 038886$

Hoskisson, R. E., Johnson, R. A., \& Moesel, D. D. (1994). Corporate Divestiture Intensity in Restructuring Firms: Effects of Governance, Strategy, and Performance. Academy of Management Journal, 37(5), 1207-1251. doi: 10.2307/256671

Jacobsen, R. (1988). The persistence of Abnormal returns. Strategic Management Journal, 9(5), 415-430. doi: 10.1002/smj.4250090503

Johnson, R. A., \& Greening, D. W. (1999). The Effects of Corporate Governance and Institutional Ownership Types on Corporate Social Performance. Academy of Management Journal, 42(5), 564-577. doi: 10.5465/256977

Kaplan, R. S., \& Norton, D. P. (1992). The Balanced Scorecard-Measures that Drive Performance. Harvard Business Review No. 92105. Retrieved from https://www.academia.edu/1180984/The_balanced_scorecard_measures_that_drive_p erformance 
Kapopoulos, P., \& Lazaretou, S. (2007). Corporate Ownership Structure and Firm Performance: evidence from Greek firms. Corporate Governance: An international Review, 15(2), 144-158. doi: 10.1111/j.1467-8683.2007.00551.x

Kim, M., \& Ritter, J. R. (1999). Valuing IPOs. Journal of Financial Economics, 53(3), 409437. doi: 10.1016/S0304-405X(99)00027-6

Kudla, R. J. (1980). Some Pitfalls in Using Certainty-Equivalents: A Note. Journal of Business Finance and Accounting, 7(2), 239-243. doi: 10.1111/j.1468-5957.1980.tb00740.x

Lee, S. H., \& Makhija, M. (2009). Flexibility in Internationalization: Is It Valuable During an Economic Crisis? Strategic Management Journal, 30(5), 537-555. doi: 10.1002/smj.742

Lindenberg, E. B., \& Ross, S. (1981). Tobin's q Ratio and Industrial Organization. Journal of Business, 54(1), 1-32. doi: 10.1086/296120

Lubatkin, M., \& Shrieves, R. E. (1986). Towards Reconciliation of Market Performance Measures to Strategic Management Research. Academy of Management Review, 11(3), 497-512. doi: 10.5465/AMR.1986.4306197

Mitchell, R. K., Agle, B. R., \& Wood, D. J. (1997). Toward a Theory of Stakeholder Identification and Salience: Defining the Principle of Who and What Really Counts. Academy of Management Review, 22(4), 853-886. doi: 10.5465/amr.1997.9711022105

Montgomery, C. A., \& Singh, H. (1984). Diversification strategy and systematic risk. Strategic Management Journal, 5(2), 181-191. doi: 10.1002/smj.4250050208

Ohlson, J., \& Gao, Z. (2006). Earnings, Earnings Growth and Value. Foundations and Trends in Accounting, 1(1), 1-70. doi: 10.1561/1400000001

Richard, P. J., Devinney, T. M., Yip, G. S., \& Johnson, G. (2009). Measuring Organizational Performance: Towards Methodological Best Practice. Journal of Management, 35(3), 718-804. doi: 10.1177/0149206308330560

Rowe, W. G., \& Morrow, J. L. (1999). A note on the dimensionality of the firm financial performance construct using accounting, market, and subjective measures. Revue Canadienne des Sciences de l'Administration, 16(1), 58-71. doi: 10.1111/j.19364490.1999.tb00188.x

Rumelt, R. P. (1974). Strategy, structure and economic performance. Cambridge: Harvard University Press.

Santos, B. J., \& Brito, A. L. (2012). Toward a Subjective Measurement Model for Firm Performance. Brazilian Administration Review, 9, 95-117. doi: 10.1590/S180776922012000500007

Seth, A. (1990). Value creation in acquisitions: A re-examination of performance issues. Strategic Management Journal, 11(2), 99-115. doi: 10.1002/smj.4250110203

Shan, Y. G., \& McIver, R. P. (2011). Corporate governance mechanisms and financial performance in China: panel data evidence on listed non-financial companies. Asia Pacific Business Review, 17(3), 301-324. doi: 10.1080/13602380903522325

Sharma, A., Branch, B., Chgawla, C., \& Qiu , L. (2013). Explaining Market-to-Book ; The relative impact of firm performance, growth, and risk. Quest of Business, 277-293. Retrieved from https://www.westga.edu/ bquest/2013/MarketToBook2013.pdf 
Shen, P. (2000). The P/E Ratio and Stock Market Performance. Federal Reserve Bank of Kansas City Economic Review, 85(4), 23-36. Retrieved from https://www.kansascityfed.org/publicat/econrev/PDF/4q00shen.pdf

Sila, I., \& Ebrahimpour, M. (2005). Critical linkages among TQM factors and business results. International Journal of Operations \& Production Management, 25(11), 1123-1155. doi: 10.1108/01443570510626925

Silverman, B. S., Nickerson, J. A., \& Freeman, J. (1997). Profitability, Transactional Alignment, and Organizational Mortality in the U. S. Trucking Industry. Strategic Management Journal, 18(S1), 31-52. doi: 10.1002/(SICI)10970266(199707)18:1+<31::AID-SMJ920>3.0.CO;2-S

Tanriverdi, H. \& Venkatraman, N. (2005). Knowledge relatedness and the performance of multibusiness firms. Strategic Management Journal, 26(2), 97-119. doi: 10.1002/smj.435

Thune, S. S., \& House, R. J. (1970). Where long-range planning pays off Findings of a survey of formal, informal planners. Business Horizons, 13(4), 81-87. doi: 10.1016/00076813(70)90162-X

Venkatraman, N., \& Ramanujam, V. (1986). Measurement of Business Performance in Strategy Research: A Comparison of Approaches. Academy of Management Review, 11(4), 801814. doi: $10.2307 / 258398$

Wahla, K., Shah, S., \& Hussain, Z. (2012). Impact of ownership structure on firm performance evidence from non-financial listed companies at Karachi Stock Exchange. International Research Journal of Finance and Economics, 84, 7-13. Retrieved from http://bit.ly/2G19nWG

Wu, W. T. (2014). The P/E Ratio and Profitability. Journal of Business \& Economics Research, 12(1), 67-76. doi: 10.19030/jber.v12i1.8380

\section{Contact information}

\section{Ing. Abu Bawa}

Tomas Bata University in Zlín, Faculty of Management and Economics

Mostní 5139, 76001, Zlín, Czech Republic

E-mail: bawa@utb.cz

ORCID: 0000-0001-7942-3169

doi: 10.7441/dokbat.2019.007 